\title{
Oxidation Behaviour of IN-738 LC Superalloys in the Presence of Ionic Salts at $1173 \mathrm{~K}$
}

\author{
M. Misbahul Amin * \\ Department of Chemistry, Faculty of Science \& Technology, University College of Science \& \\ Technology Malaysia, Mengabang Telipot, 21030 Kuala Terengganu, Malasya.
}

Received 14 July 2003; accepted in revised form 11 November 2003

\begin{abstract}
Oxidation of the alloy having nominal composition $\mathrm{Ni}-16 \mathrm{Cr}-8.5 \mathrm{Co}(\mathrm{wt} . \%)$ was studied in the presence of $\mathrm{KCl}$ and $\mathrm{K}_{2} \mathrm{CO}_{3}$ at $1173 \mathrm{~K}$ in air. Chemical composition of oxide scales and scale morphologies were determined by means of $\mathrm{X}$-ray diffraction analysis and scanning electron microscopic studies. The oxide scales of $\mathrm{KCl}-$ and $\mathrm{K}_{2} \mathrm{CO}_{3}$ - coated alloys showed complex microstructures and compositions. This behaviour was ascribed to the release of volatile metallic chlorides, evolution of $\mathrm{CO} / \mathrm{CO}_{2}$ gas as well as formation of fluxing products. The high temperature oxidation resistance is not only related to the nature of the passive film but is also strongly dependent on the salt environments and the structure of alloy.
\end{abstract}

Keywords: Oxidation, IN-738 LC Alloy, $\mathrm{KCl}, \mathrm{K}_{2} \mathrm{CO}_{3}$.

\section{Introduction}

Nickel-based alloys containing chromium as a major constituent together with cobalt, titanium and aluminium additions are the most widely used materials in turbine blades of jet engines, nuclear power reactors and land-based turbines.

Among a great variety of protective systems to increase the scaling resistance of super-alloys the overlay $\mathrm{M}-\mathrm{Cr}$ coatings (where $\mathrm{M}=\mathrm{Ni}, \mathrm{Co}$ ) offer an advantage of appreciable compositional flexibility. The aluminium addition provides good oxidation resistance where relatively high chromium and cobalt levels ensure hot corrosion resistance. Compositional modification of the overlay coatings, particularly of the Cr:Co ratio, makes them suitable for a variety of service

\footnotetext{
*Corresponding author. E-mail:misbah@kustem.edu.my;mmamin@lycos.com.
} 
conditions. Oxidation and hot corrosion behaviour of $\mathrm{M}-\mathrm{Cr}$ materials alone or deposited on superalloys substrates have been a subject of many investigations [1-8]. The role of alkali earth metal salts inducing high temperature oxidation studies has been reported [9-12]. The passivity of nickel in $\mathrm{Na}_{2} \mathrm{SO}_{4} / \mathrm{NaCl}$ melts, in air, is destroyed by $\mathrm{SO}_{3}, \mathrm{SO}_{2}$, and $\mathrm{O}_{2}[13,14]$. Blistering and cracking produced by $\mathrm{NaCl}$ exposure have been attributed to the formation of volatile metallic chlorides, like $\mathrm{NiCl}_{2}, \mathrm{CrCl}_{3}$ in locally reducing environments [15-17]. Limited attention has been paid to the morphology of attack on nickel-base alloys in the presence of potassium in $\mathrm{KCl}$ and $\mathrm{K}_{2} \mathrm{CO}_{3}$, although chlorides transform to oxides releasing $\mathrm{Cl}_{2}$ gas under oxidizing atmospheres [18-20]. The purpose of this work was to get information on high temperature corrosion of $\mathrm{Ni}-16 \mathrm{Cr}$ $8.5 \mathrm{Co}$ alloy in the presence of $\mathrm{KCl}$ and $\mathrm{K}_{2} \mathrm{CO}_{3}$, oxidized at $1173 \mathrm{~K}$ in air, including oxidation kinetics as well as structure and morphologies of oxide scales.

\section{Experimental}

The alloy having nominal compositions $\mathrm{Ni}-16 \mathrm{Cr}-8.5 \mathrm{Co}$ (wt. \%) was obtained and homogenized for $4 \mathrm{~h}$ in an evacuated $\left(10^{-2} \mathrm{~Pa}\right)$ quartz tube at $1173 \mathrm{~K}$. Chemical compositions of the experimental alloy are given in Table 1. The ingots were spark-machined to get flat discs, diameter of $15 \mathrm{~mm}$ and thickness of $1 \mathrm{~mm}$, which were ground on $\mathrm{SiC}$ papers up to 800 grit no., then finally degreased in water with detergent and ultrasonically cleaned in acetone.

The polished specimens were uniformly coated with thin films of $\mathrm{KCl}$ or $\mathrm{K}_{2} \mathrm{CO}_{3}$. The specimens were heated to about $573 \mathrm{~K}$ and were sprayed with aqueous solutions of the salt till a nearly uniform coating (about $6 \mu \mathrm{m}$ thick coatings) of the salt was obtained. The salt coated specimens were dried in an oven for about $1 \mathrm{~h}$, cooled to room temperature and weighed. The salt coated specimens were then used for high temperature oxidation studies. 
Table 1. Chemical composition of IN-738 LC superalloy (wt.\%).

\begin{tabular}{cccccccc}
\hline $\mathrm{Co}$ & $\mathrm{Cr}$ & $\mathrm{Al}$ & $\mathrm{Si}$ & $\mathrm{C}$ & $\mathrm{P}$ & $\mathrm{Fe}$ & $\mathrm{B}$ \\
\hline 8.59 & 16.08 & 3.43 & 0.18 & 0.11 & 0.01 & 0.50 & 0.05 \\
\hline $\mathrm{S}$ & $\mathrm{W}$ & $\mathrm{Ta}$ & $\mathrm{Nb}$ & $\mathrm{Ti}$ & $\mathrm{Mn}$ & $\mathrm{Cu}$ & $\mathrm{Ni}$ \\
\hline 0.01 & 2.67 & 1.75 & 0.90 & 3.38 & 0.03 & 0.03 & $\mathrm{Bal}$ \\
\hline
\end{tabular}

Kinetic studies on the oxidation of coated IN-738 LC superalloy were carried out at $1173 \mathrm{~K}$ in air for periods up to $48 \mathrm{~h}$. The coated specimens were transferred into silica buckets and suspended by helices in a helical thermal balance using a vertical tubular furnace. Variation in mass change was recorded at intervals of every $4 \mathrm{~h}$.

Table 2. Constituent identified in the scales by X-ray diffraction analysis, IN-738 LC superalloy, $\mathrm{KCl}$ - and $\mathrm{K}_{2} \mathrm{CO}_{3}$ - coated specimen, oxidized at $1173 \mathrm{~K}$ for $48 \mathrm{~h}$ in air.

\begin{tabular}{lc}
\hline Salt environment & Constituent identified in the scales \\
$\mathrm{KCl}$ & $\mathrm{Cr}_{2} \mathrm{O}_{3}, \mathrm{NiO}, \mathrm{K}_{2} \mathrm{CrO}_{4}, \mathrm{CrCl}_{3}$, \\
& $\mathrm{NiCl}_{2}, \mathrm{~K}_{2} \mathrm{NiO}_{2}, \mathrm{Al}_{2} \mathrm{O}_{3}, \mathrm{Co}_{3} \mathrm{O}_{4}$ \\
& \\
$\mathrm{~K}_{2} \mathrm{CO}_{3}$ & $\mathrm{Cr}_{2} \mathrm{O}_{3}, \mathrm{NiO}, \mathrm{K}_{2} \mathrm{CrO}_{4}, \mathrm{Al}_{2} \mathrm{O} 3$, \\
& $\mathrm{Co}_{3} \mathrm{O}_{4}, \mathrm{~K}_{2} \mathrm{NiO}_{2}$ \\
\hline
\end{tabular}

Oxide scales of coated IN-738 LC superalloy were examined by taking crosssections of the specimens, conventionally mounted and polished to a $1 \mu \mathrm{m}$ diamond finish, in a scanning electron microscope, Jeol JSM-35. After oxidation studies, the representative specimens were examined by X-ray diffraction analysis. The various constituents were identified using a Phillip PW-1730 X-ray diffractometer fitted $\mathrm{Fe}$-, $\mathrm{Co}$, or $\mathrm{Cu}-\mathrm{K} \alpha$ targets. Table 2 summarizes the results of the XRD analysis. 


\section{Results}

The oxidation kinetic data are shown in Fig. 1 for IN-738 LC superalloy with $\mathrm{KCl}$ and $\mathrm{K}_{2} \mathrm{CO}_{3}$, oxidized at $1173 \mathrm{~K}$ in air for $48 \mathrm{~h}$. The oxidation rate of $\mathrm{KCl}-$ induced specimens result mass gain with increasing time up to $32 \mathrm{~h}$ followed by a decrease in mass at longer time. $\mathrm{K}_{2} \mathrm{CO}_{3}$-coated specimens exhibit invariable mass loss during the first $28 \mathrm{~h}$ after which there was mass gain with further increase in time. This could be attributed to the evolution of $\mathrm{CO} / \mathrm{CO}_{2}$ gas which facilitates oxidation attack $[21,22]$.

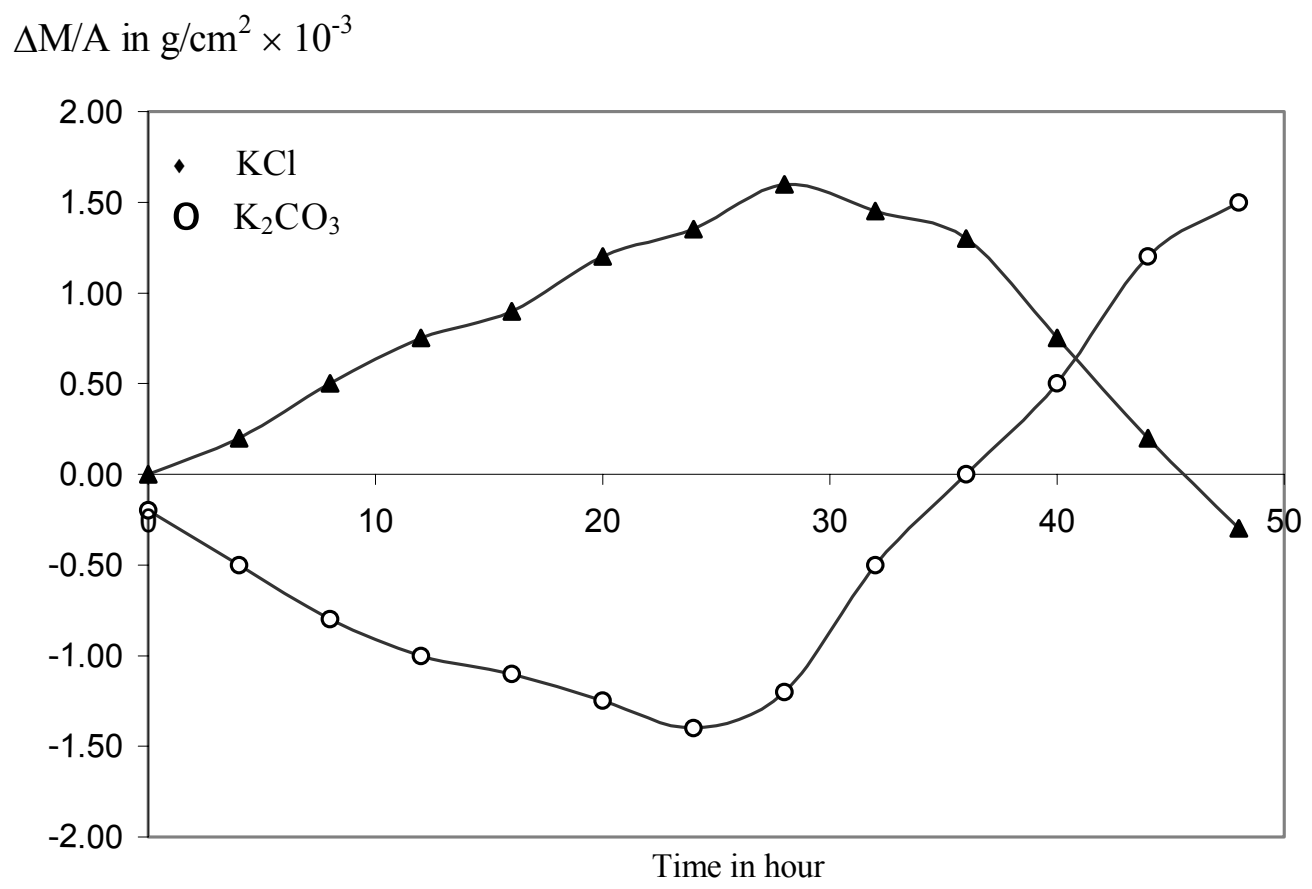

Figure 1. The change in mass with time (oxidation kinetics) for IN-738 LC superalloy coated with $\mathrm{KCl}$ and $\mathrm{K} 2 \mathrm{CO} 3$, oxidized at $1173 \mathrm{~K}$ in air for $48 \mathrm{~h}$.

The scales are separated from substrate at some regions, possibly due to polishing artifacts. The chlorides of chromium and nickel form the outer layers of scales incorporated with $\mathrm{Cr}_{2} \mathrm{O}_{3}$ and $\mathrm{NiO}$ (Fig. 2). $\mathrm{Cr}_{2} \mathrm{O}_{3}$ has not been found in the inner scales. This might be due to the formation of intermediate volatile species $\mathrm{CrO}_{2} \mathrm{Cl}_{2}$, some of which evaporates and condenses on the walls of the reaction tube and some of it decomposes and accumulates at the alloy/salt interface in the 
form of $\mathrm{Cr}_{2} \mathrm{O}_{3}$ [23]. It appears that during cooling of fluxed mass, stresses are developed resulting in the production of cracks and voids [24].

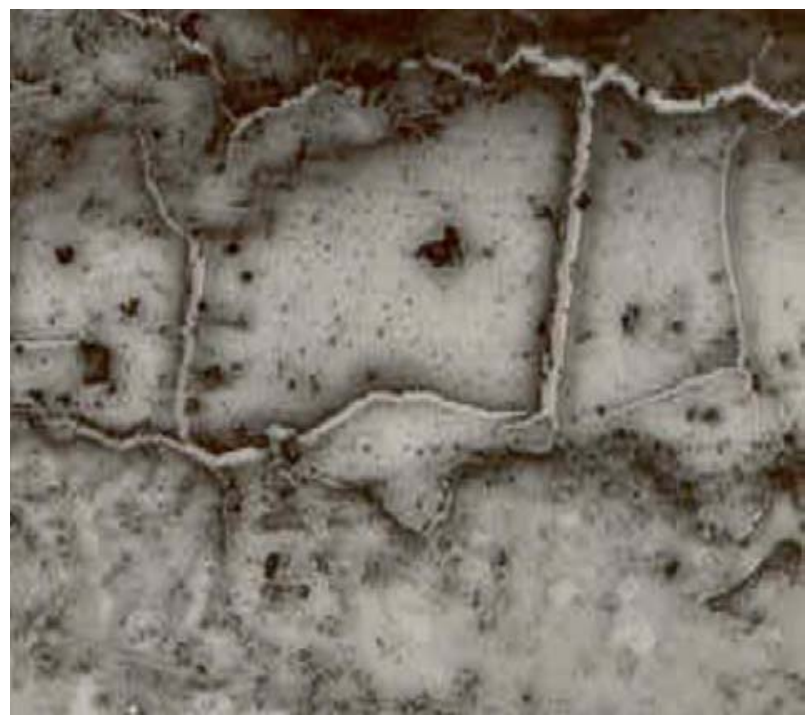

Figure 2. Scale morphology of IN-738 LC superalloy coated with $\mathrm{KCl}$, oxidized at $1173 \mathrm{~K}$ for $48 \mathrm{~h}$ in air.

The inner oxide scales of $\mathrm{K}_{2} \mathrm{CO}_{3}$-coated corroded alloy mainly consist of $\mathrm{Cr}_{2} \mathrm{O}_{3}$ layers followed by $\mathrm{NiO}$ layers (Fig. 3); the middle layers of the scales represent fluxing products such as $\mathrm{K}_{2} \mathrm{CrO}_{4}, \mathrm{NiCrO}_{4}$ and probably $\mathrm{K}_{2} \mathrm{NiO}_{2}$ [25].

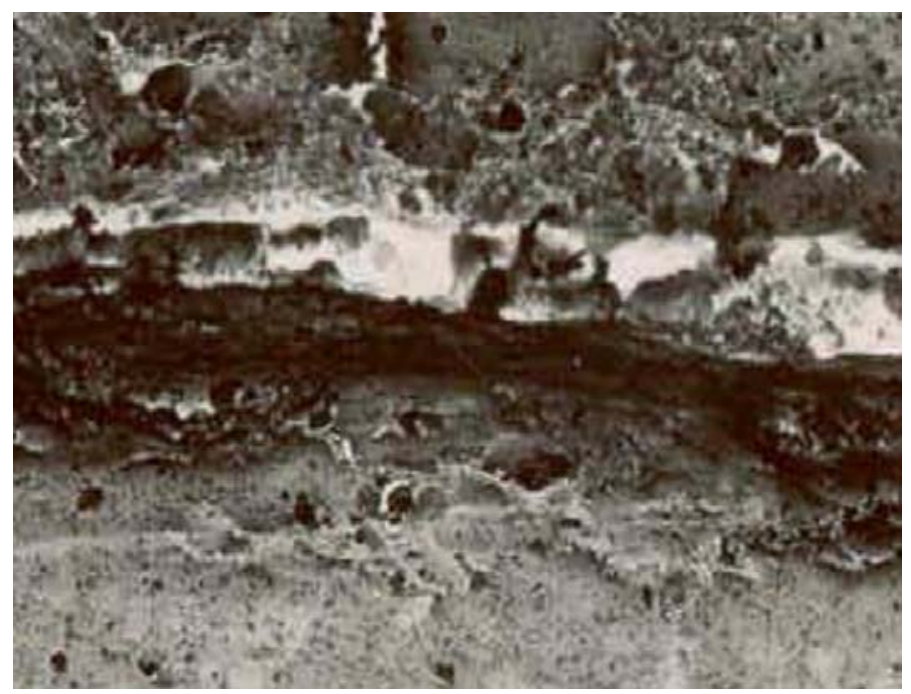

Figure 3. Scale morphology of IN-738 LC superalloy coated with $\mathrm{K}_{2} \mathrm{SO}_{4}$, oxidized at $1173 \mathrm{~K}$ for $48 \mathrm{~h}$ in air. 
The outer scales represent layered structures comprising of $\mathrm{Cr}_{2} \mathrm{O}_{3}$ and $\mathrm{NiO}$ precipitated from the fluxing product at the salt/air interface. The presence of micro-pores is perhaps the result of evolved $\mathrm{CO} / \mathrm{CO}_{2}$ from $\mathrm{K}_{2} \mathrm{CO}_{3}$. The crystalline constituents appearing in the middle layers of the scale represent oxides and chromates crystallized out during cooling of the fluxing product after completion of the oxidation run. The formation of a stratified structure of the oxide scales is as that described earlier for $\mathrm{Ni}-20 \mathrm{Cr}$ and Fe-20Cr alloys [26, 27].

\section{Discussion}

IN-738 LC corrodes to very large extent in the presence of $\mathrm{KCl}$. The ease of formation of a volatile chloride seems to be the rate determining factor in the high temperature oxidation of the alloy. There is the formation of volatile $\mathrm{CrO}_{2} \mathrm{Cl}_{2}$ by the interaction of $\mathrm{Cr}_{2} \mathrm{O}_{3}$ and $\mathrm{KCl}$ and its subsequent conversion into volatile $\mathrm{K}_{2} \mathrm{CrO}_{4}$.

The $\mathrm{NiO}$ also reacts with $\mathrm{KCl}$ to form volatile $\mathrm{NiCl}_{2}$. In both cases when the chloride comes into contact with air it is converted into oxide [26]. The presence of $\mathrm{KCl}$ and $\mathrm{K}_{2} \mathrm{CO}_{3}$ indicates that the corrosion rates are influenced not only by the nature of the salt but on the amount of the salt deposited on the alloy as well as time.

The aggressive action of $\mathrm{KCl}$ can be attributed to several factors, mainly:

1. Reaction of molten $\mathrm{KCl}$ with oxide scales forming chlorides and not moltenfluxing products

$$
\begin{aligned}
12 \mathrm{KCl}+5 \mathrm{Cr}_{2} \mathrm{O}_{3}+9 / 2 \mathrm{O}_{2} & \rightarrow 6 \mathrm{~K}_{2} \mathrm{CrO}_{4}+4 \mathrm{CrCl}_{3} \\
2 \mathrm{KCl}+\mathrm{Cr}_{2} \mathrm{O}_{3}+3 / 2 \mathrm{O}_{2} & \rightarrow \mathrm{CrO}_{2} \mathrm{Cl}_{2}+\mathrm{K}_{2} \mathrm{CrO}_{4} \\
2 \mathrm{KCl}+\mathrm{NiO} & \rightarrow \mathrm{NiCl}_{2}+\mathrm{K}_{2} \mathrm{O} \\
\mathrm{NiO}+\mathrm{K}_{2} \mathrm{O} & \rightarrow \mathrm{K}_{2} \mathrm{NiO}_{2}
\end{aligned}
$$


2. After reaction with the oxide scales, the molten $\mathrm{KCl}$ further attacks the alloy substrate forming metal halides $[15,25]$ :

$$
\begin{aligned}
& 4 \mathrm{KCl}+2 \mathrm{Ni}+\mathrm{O}_{2} \quad \rightarrow \quad 2 \mathrm{NiCl}_{2}+2 \mathrm{~K}_{2} \mathrm{O} \\
& 2 \mathrm{~K}_{2} \mathrm{O}+2 \mathrm{Ni}+\mathrm{O}_{2} \quad \rightarrow \quad 2 \mathrm{~K}_{2} \mathrm{NiO}_{2} \\
& 12 \mathrm{KCl}+4 \mathrm{Cr}+3 \mathrm{O}_{2} \quad \rightarrow \quad 4 \mathrm{CrCl}_{3}+6 \mathrm{~K}_{2} \mathrm{O} \\
& 4 \mathrm{KCl}+2 \mathrm{Cr}+3 \mathrm{O}_{2} \quad \rightarrow \quad 2 \mathrm{CrO}_{2} \mathrm{Cl}_{2}+2 \mathrm{~K}_{2} \mathrm{O} \\
& \mathrm{CrO}_{2} \mathrm{Cl}_{2}+2 \mathrm{~K}_{2} \mathrm{O} \quad \rightarrow \quad \mathrm{K}_{2} \mathrm{CrO}_{4}+2 \mathrm{KCl}
\end{aligned}
$$

The formation of some volatile products like $\mathrm{CrO}_{2} \mathrm{Cl}_{2}, \mathrm{~K}_{2} \mathrm{CrO}_{4}$ and volatile halides exert sufficient vapour pressure so as to break the protective scale.

3. The chlorides formed by (1), (2) and (3) are released at the air/salt interface and get oxidized to release chlorine gas.

$$
\begin{aligned}
4 \mathrm{CrCl}_{3}+3 \mathrm{O}_{2} & \rightarrow 2 \mathrm{Cr}_{2} \mathrm{O}_{3}+6 \mathrm{Cl}_{2} \\
4 \mathrm{CrO}_{2} \mathrm{Cl}_{2} & \rightarrow 2 \mathrm{Cr}_{2} \mathrm{O}_{3}+\mathrm{O}_{2}+4 \mathrm{Cl}_{2} \\
2 \mathrm{NiCl}_{2}+\mathrm{O}_{2} & \rightarrow 2 \mathrm{NiO}+2 \mathrm{Cl}_{2}
\end{aligned}
$$

4. The chlorides might be entrapped between inner oxide layers of the alloy and get condensed on cooling and appear distinct and discrete phase(s) in the scale. The relative ease of formation and volatility of some chlorides can be shown by thermodynamic and thermochemical data reported by [28, 29]. Since the melting point of $\mathrm{NiCl}_{2}(1303 \mathrm{~K})$ and $\mathrm{CrCl}_{3}(1423 \mathrm{~K})$ at the vapour pressure of chlorides is $10^{-4} \mathrm{~Pa}$.

The high temperature oxidation behaviour of $\mathrm{K}_{2} \mathrm{CO}_{3}$-coated alloy seems to be aggressive, being an active oxidizing agent providing oxygen during fluxing reaction. However, due to profuse evolution $[21,22]$ of $\mathrm{CO} / \mathrm{CO}_{2}$, heavy mass 
losses are observed up to $28 \mathrm{~h}$ during corrosion and scales are porous. The consequence of fluxing and evolution of gases are caused the cracking or disruption of the scales with the result that the fused salt would come in contact with fresh metal resulting in high corrosion rates.

$\mathrm{K}_{2} \mathrm{CO}_{3}$ (m.p. $1164 \mathrm{~K}$ ) decomposes in the following manner:

$$
\begin{gathered}
\mathrm{K}_{2} \mathrm{CO}_{3} \rightarrow \mathrm{K}_{2} \mathrm{O}+\mathrm{CO}_{2} \\
4 \mathrm{~K}_{2} \mathrm{CO}_{3}+2 \mathrm{Cr}_{2} \mathrm{O}_{3}+3 \mathrm{O}_{2} \rightarrow 4 \mathrm{~K}_{2} \mathrm{CrO}_{4}+4 \mathrm{CO}_{2} \\
\mathrm{~K}_{2} \mathrm{CO}_{3}+\mathrm{NiO} \rightarrow \mathrm{K}_{2} \mathrm{NiO}_{2}+\mathrm{CO}_{2}
\end{gathered}
$$

$\mathrm{KCl}$-induced hot corrosion involves fluxing-oxidation reactions while $\mathrm{K}_{2} \mathrm{CO}_{3}$ coated specimens seem to behave aggressive due to the evolution of $\mathrm{CO}_{2}$, having losses incurred as a result of decarburization and ease in the availability of $\mathrm{O}^{2-}$ from basic carbonates.

\section{Conclusion}

The following conclusions can be drawn on the investigation of oxidation behaviour of IN-738 LC superalloys carried out at $1173 \mathrm{~K}$ in air for $48 \mathrm{~h}$.

During the reaction of liquid $\mathrm{KCl}$ with oxide scales, chlorides and fluxing products are formed and some volatile products like $\mathrm{CrO}_{2} \mathrm{Cl}_{2}$, and $\mathrm{K}_{2} \mathrm{CrO}_{4}$ and metallic chlorides such as $\mathrm{NiCl}_{2}$ and $\mathrm{CrCl}_{3}$, which exert sufficient vapour pressure so as to break the protective scales.

In $\mathrm{K}_{2} \mathrm{CO}_{3}$-coated corrosion, the appearance of porous and copious scales is attributed to the profuse evolution of $\mathrm{CO}_{2}$ and fluxing of protective scales.

\section{Acknowledgement}

The author is grateful to Prof. Dr. Md. Hamiuddin, Z.H. College of Eng. \& Tech., AMU, India, for the provision of X-ray Diffraction and SEM studies. The financial assistance in the form of short term grant: 54099 from KUSTEM, Malaysia is thankfully acknowledged. 


\section{References}

1. F.J. Pennisi, D.K. Gupta, Thin Solid Films 84 (1981) 49.

2. T.N. Rhys-Jone (Protective Oxide Scales on Superalloys and Coatings Used in Gas Turbine Blades and Vanes Applications), Mat. Sci. 4 (1988) 421.

3. D.A. Shores, Corrosion 13 (1975) 434.

4. D.K. Gupta, D.S. Duvall, "Superalloys 1984", Proc. $5^{\text {th }}$ Intnl. Symp. on Superalloy, Seven Springs, Champion, PA, Oct. 7-11,1984, p. 71.

5. C.A.C. Sequeira, M.G. Hocking, J. Appl. Chem. 8 (1978) 152.

6. C.G. McGreath, Mat. Sci. Eng. 88 (1987) 303.

7. B.L. Tremillon, G. Picard, Proc. $1^{\text {st }}$ Intnl. Symp. on Molten Salt Chemistry and Technology, Y. It, Ed. Kyoto, 1978, p. 1246.

8. J.R. Vargas, "Metallurgical 80", Conf. Proc., San Diego, C. A.,Vol. II, J.N. Zemel (Ed.), Elsevier Sequoia, Lausanne, 1980, p. 407.

9. G. Picard, H.M. Lefebure, B.L. Tremillon, Proc. $5^{\text {th }}$ Intnl. Conf. on Molten Salts, Las Vegas, Oct. 13-18, 1985, p. 428.

10. Thermal Convention Loop Corrosion Tests of 31655 and IN-800 in Molten Salts, Sandia Report 81-8210, 1982, p. 654.

11. L.V. Shelton, R.S. Carlton, J. Eng. Gas Turbine Power, Trans. ASME 106 (1984) 819.

12. A.J.B. Cutler, Mat. Sci. Technol. 3 (1987) 512.

13. Y. Shinata, Y. Nishi, "Hot Corrosion of Ni-20Cr base alloys induced by $\mathrm{Na}_{2} \mathrm{SO}_{4}, \mathrm{NaCl}$ mixtures", Proc. JIMIS-3, High Temp. Corrosion JIM Supplement, 1983, p. 386.

14. W.L. Fielder, C.A. Stearns, F.J. Kohl, "Reactions of $\mathrm{NaCl}$ with gaseous $\mathrm{SO}_{3}$, $\mathrm{SO}_{2}$, and $\mathrm{O}_{2} "$, NASA-TM 83423, NASA Scientific and Technical Information Branch, Washington D.C., 1983, p. 1553.

15. F.J. Kohl, C.A. Stearns, G.C. Fryburg, "The role of $\mathrm{NaCl}$ in flame chemistry, in the deposition process, and its reaction with protective oxides", Proc. $4^{\text {th }}$ US/UK Navy Conf. on Gas Turbine Materials in a Marine Environment, Vol. II, U.S. Naval Sea Command, Annapolis, MD, 1979, p. 565.

16. S.Y. Liu, C.L. Lee, C.H. Kao, T.P. Perng, Corrosion 56 (2000) 338. 
17. A. Dais, V.F. Cunha Lins, Corros. Sci. 40 (1998) 273.

18. P. Hancock, Corros. Sci. 22 (1982) 51.

19. M.M. Amin, Bull. Chem. Soc. Ethiop. 7 (1993) 94.

20. M. Stratmann, K. Hoffmann, Corros. Sci. 29 (1989) 1329.

21.O.F. Devereux, K.Y. Kim, K.S. Yeum (Reactions at the Corroding Nickel Electrode in Molten Sodium Carbonate under $\mathrm{CO} / \mathrm{CO}_{2}$ Atmosphere), Corros. Sci. 23 (1983) 216.

22. M. Amin (Hot Corrosion Behaviour of Inconel-600Alloy in Presence of $\mathrm{NaCl}$ and $\mathrm{Na}_{2} \mathrm{CO}_{3}$ at $850{ }^{\circ} \mathrm{C}$ ), Prakt. Metallogr. 30 (1993 ) 240.

23. M.M. Amin (Effect of Some Salt Coatings on the High Temperature Oxidation of Nimonic-80A Alloy at 1173 K), Thin Solid Films 299 (1997) 3.

24. P.J. Smith, W.W. Smeltzer, Oxid. Met. 28 (1987) 291.

25. M.M. Amin (The CsCl- and CsNO3-induced High Temperature Oxidation of Nimonic-90 Alloy at 1123 K), Appl. Surf. Sci. 115 (1996) 358.

26. A.U. Malik, M.M. Amin, S. Ahmed, Transact. Jpn. Inst. Met. 25 (1984) 172.

27. T.Kr. Aune, O. Lunder, K. Nisancioglu, Microstructural Science 17 (1988) 232.

28. M.C. Ball, A.H. Norbury, "Physical Data for Inorganic Chemists", Longman Group Ltd., (1974).

29. P.L. Daniel, R.A. Rapp (Advances in Corrosion Science and Technology), Corros. Sci. 5 (1976) 55. 